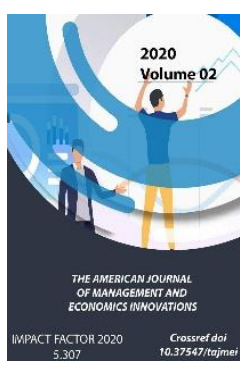

\title{
Methodological Basis Of Increasing Youth Activity In The Reform Of The Economy In The Period Of Modernization
}

\author{
Raxmonov Abdurauf Muxammedovich \\ Tashkent Institute Of Finance Senior Teacher Of The Department" Social Sciences", Tashkent \\ City, Uzbekistan
}

Copyright: Original content from this work may be used under the terms of the creative commons attributes 4.0 licence.

\section{ABSTRACT}

The article highlights the issues of increasing youth activity in the process of economic reforms in the society today.

\section{KEYWORDS}

Modernization, technological, entrepreneurship, civil society, conception, investment, political activity, social movement, social activity, demography.

\section{INTRODUCTION}

The development of the country from the present point of view is a link to the economic modernization of society. In this regard, it can be said that the growing competitive environment during the development period as well as the constantly changing economic requirements require a more recent approach to issues related to the modernization of production, its technical and technological upgrades.

At this time, it is time to pay attention to the sphere of effective stimulation in order to constantly modernize production in technological terms. 


\section{MATERIALS AND METHODS}

From these considerations it can be seen that the modernization of production requires initiative, creative approach. We must also recognize that young people in our country stand in the leading places. Because they are creators who aspire to innovation. Although there are many factors that determine the development of the country, the economy occupies a leading position. At present, the interest of our young people in such areas as entrepreneurship, farming, small business is growing. Therefore, it is necessary to pay attention to this issue seriously, to solve the problems of increasing the employment and well-being of the population of the country on this basis, earlier due to the modern demand of business and private entrepreneurship, to promote the rapid development in various ways.

Modernization this layer of society, which is the basis of social, economic, political growth in the development of each sphere, is a direct link to the spirituality, scientific potential of young people. (Picture 1)

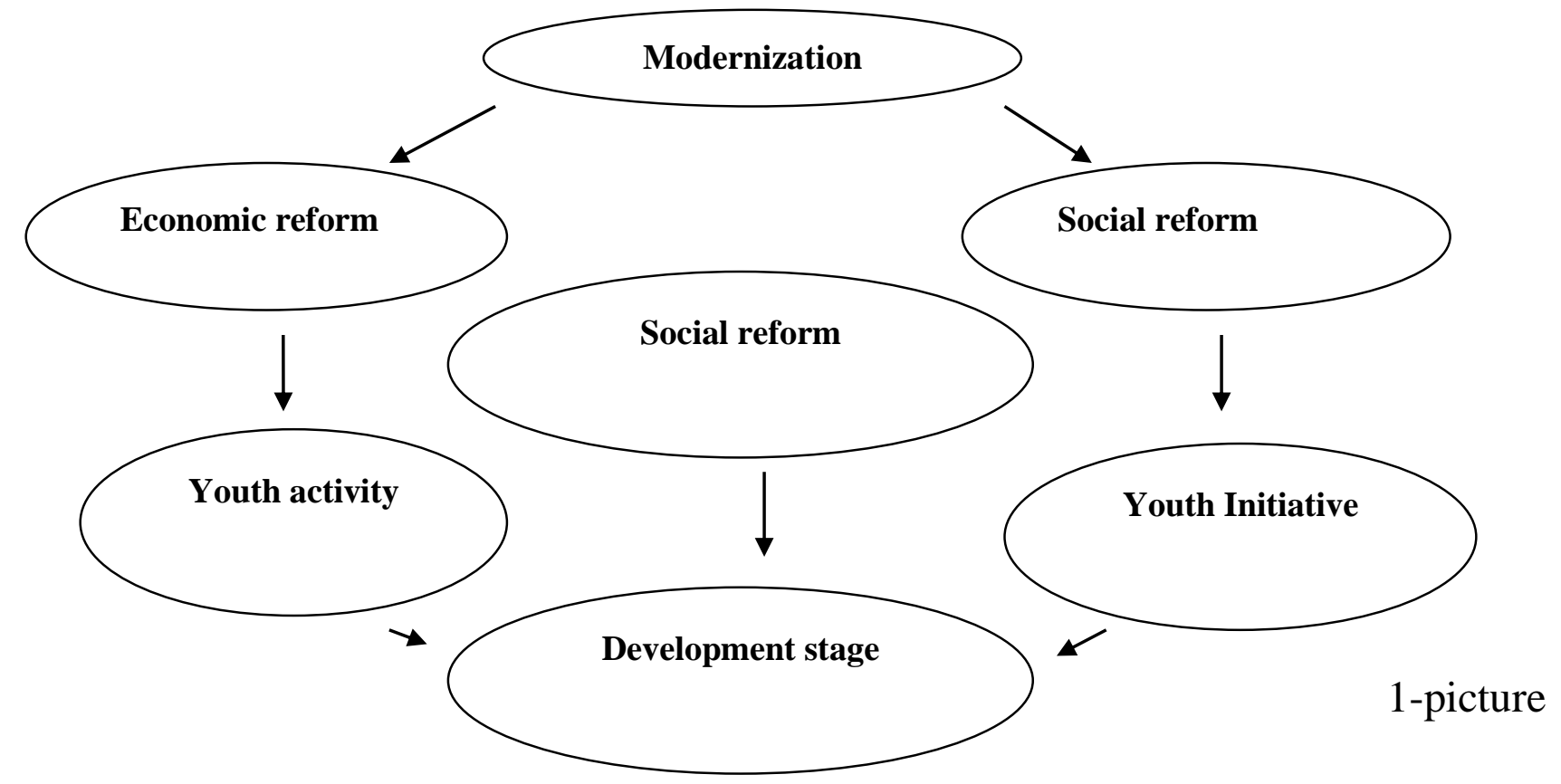

The announcement of the current year as the "year of development of Science and education and the digital economy" and the great attention paid to young people in particular this year, which in turn allows us to carry out large-scale measures aimed at creating in our country all the conditions necessary for the upbringing of physically and morally healthy, harmonious generation, capable[1]
Ensuring more peace and stability of the population of our country, strengthening its independence and improving other processes for human interests is one of the important and main tasks of modernization. It remains so long as human life exists. Strengthening independence, democratization of society, development and renewal of civil society will remain a high priority goal and task. On this basis, it is possible and necessary to solve the problems of development in the country. 
As defined in the principles, in the modernization of society, the social protection of people, the economy, the exclusion from politics are attributed to its internal laws, self regulating conditions, inchinun, youth.

In the process of modernization of society, it is extremely important to pay serious attention to management. The fact is that the management of the market economy also does not take place without the activities of young people. To do this, the formation of a financial and banking system that meets the requirements of a market economy is a period requirement. It is not uncommon for young people who achieve a specialty by taking knowledge in this field. These young people play an extremely important role in the modernization of society, especially in the further liberalization of the economy, the implementation of profound structural changes in the economy.

In short, in the process of modernization, young people should be aware of the fact that the country's economy is developing in a consistent manner. According to scientists of the world, five basic rules are the core of the program on the construction of the state and reform of the economy of Uzbekistan. President Sh.In the Constitution of "Mirziyoyev" economic activity, entrepreneurship, equality of all forms of ownership and protection of the state are guaranteed.

A new concept of improving the tax policy was adopted in order to accelerate the development of the economy and increase the investment attractiveness of our country. This document project was widely and thoroughly discussed by the public, business community, international financial organizations, influential experts of our country.
On the basis of the new concept, significant changes were introduced in the tax policy. In particular, instead of the highest 22.5 percent income tax rate, which was valid for individuals until later periods, the highest 12 percent rate was set, while the 8 percent insurance fee was canceled.

The single social payment rate, which is considered the hardest for the business community, was set to 25 percent instead of 12 percent.

The compulsory payment of 3,2 percent to nonbudgetary pension, road and education funds was canceled.

The rates of customs duties were revised and the rates of excise taxes on goods decreased by about 3,5 thousand tons and goods by about 800 thousand tons.

The state duty on raw materials, as well as equipment and technology for products that are not manufactured in our country has become non-deductible.

Planned verification of financial economic activity of business entities was canceled. 138 licensing and authorization requirements have been simplified, 42 of which have been completely liquidated."[1] many scholars have also expressed their views on economic reforms and politics. "This principle in the life of independent Uzbekistan has confirmed the particular necessity of life. After all, the people of the Republic know well the periods when politics put pressure on the economy. Exactly the same situation in the time of the former union caused a negative impact on the social standard of living of the population. For this reason, the economy was also not sufficiently developed. During the transition to market relations, it is possible to effectively develop other areas, when economic life becomes a leader. The task of ideology during this period 
was to ensure the peace and tranquility of the population in society.[2] Understanding the sides of the economy also depends on political consciousness. "The ability to enter into political relations with a high awareness of events and achieve political effects is political consciousness."[3] political consciousness is also the basis of youth social activity. When we say the political activity of young people, it is understood that they have the right to participate in the affairs of Public Administration, have a serious impact on the direction of the activities of the state, have the right to elect and be elected, actively participate in the reform of society, have the right to private property and ensure its inviolability, be able

There are different approaches to explaining the concept of political activism. We can not agree with the definitions that"political activity is the activity of a social group or individual aimed at improving, changing the socioeconomic or political order "[4] or"political activity is the manifestation in certain forms of life expectancy of certain persons of their aggregate activity, which reflects the active participation in political processes, protecting their political rights and interests" [5]. Because, even in the above definitions, youth activity is not fully described, the definitions have the property of a narrow approach, and different directions of society are not covered.

In our opinion, the political activity of young people is an activity in the social movement, aimed at updating the political and economic system of society, its active participation in developmenttirishga and ensuring the freedom, prosperity, independence of Vatan.

The political activity of young people is reflected in the directions of modernization of the society under construction in this country, the conduct of radical reforms, the transition to market relations, the creation of a democratic, civil society. The political activity of young people is reflected in their organization in various associations and movements, with the help of which the state creates opportunities for the use of benefits and guarantees given to young people, as well as their participation in ensuring the implementation of government decisions that help increase the personal right of young people and its role in society.

President Sh.Mirziyoyev emphasized that "our most basic achievement is the ability of our multinational people to overcome the difficulties and trials that arise, the modern worldview, political consciousness and social activity are increasing, they live without neglecting the events around us, on the contrary, with a sense of inviolability"[6], and in the mentality of our nation, which is aimed at solving the high

Austerity was not only the understanding that the economy is the primary for mankind, but it was also the recommendation of the individual to manage his activities in these areas. In this place, one of the negative vices that occur among people is the betrayal of an economic Deposit.

Our ancestors used to have a high level of thinking in economic, political, spiritual and legal terms. These areas have defined their activity.

After all, in state bodies, managers with different specialties conduct business. Now a large part of this is young people. On this occasion Sh.M.Mirziyoyev " proud and proud of all of us, being able to rightly assume responsibility for the future of our homeland, becoming the decisive power of today and tomorrow, is the opportunity for young people to take responsibility for the future of our country. 
It is necessary to bring to the logical end our extensive work in this area, in particular, our national programs on education and training."[7]

The activity of young people in the economic sphere consists in the creation of products in the material and spiritual processes necessary for the lifestyle of a person by working in economic entities of different spheres of society. The economic activity of young people is manifested in their serious share in the development of the economic system of society, in their activities in business and entrepreneurial structures, in public organizations, enterprises and institutions. The greater their share, the higher their role in the economic life of society. The main content and essence of the economic activity of young people is to achieve economic fullness in society as well as a large number of production of consumer products.

One of the ways to increase the economic, spiritual and educational activity of young people is to create conditions for them to participate in production, through employment. Through Labor, young people will be able to meet not only their material, but also spiritual and educational needs, improve their knowledge and skills, pay attention to their health.

It is known that the peculiarities of the development of the economy, the privatization of existing property, the maintenance of macroeconomic stability, entrepreneurship in the production of the state, the creation of a legislative framework for the implementation of reforms and the formation and observance of a strong social protection system are an indicator.

\section{DISCUSSIONS AND RESULTS}

The main goal of the economic policy of Uzbekistan is the gradual implementation of the foundations of civilized and strong socially oriented market relations, that is, the transition from quantitative changes to qualitative changes should be carried out not in a revolutionary way, but in an evolutionary way. The driving force in the current conditions of Uzbekistan is the social layer of the owners. Now this moving force, the social layer, is trying to become a class of proprietors. The establishment of a real estate class in the Republic is a guarantee of irreversibility of the process of economic reform. The class of proprietors is a force that restores the necessary conditions for the development of the market economy, promotes movement, changes towards market relations. The stable economic development of Uzbekistan is the cornerstone of national independence, independence and prosperity of the country. To do this, we believe that the implementation of the following tasks is a guarantee. In the process of modernization:

- Inclusion of Uzbekistan in the structure of modern economic system developed in accordance with international standards and developed in the world;

- Rapid development of national production oriented to abroad, increasing the competitive range of products produced in the world market, in our country, ultimately increasing the state position, increasing the lifestyle and economic opportunities of the people;

- Achieve intensive development of Agrarian orientationtirishga and others;

Consequently, in the process of modernization, with the help of business, and entrepreneurship, the flow of relations between economic conduct and economic 
entities in production occurs. After all, there is a role of young people in it. Business and entrepreneurship this is an activity that, independently, on the basis of its own responsibility, is in an effort to achieve certain economic viability, even if it risks its personal property, or is intended to generate income. However, there are different opinions among Economist scientists about business, entrepreneurship. For Example, B.A.Rayzberg argues that"entrepreneurship can be considered as an independent factor because it kuchaytiradis a key three-factor movement as a production, revenue generating force" [8]. A.V.And Shestakov admits that"entrepreneurship is the activity of using material resources in the best possible way to generate income and multiply its property on the basis of risking economic activity by its actions" [9]. V.Eat it.llyukhin, however, understands that "entrepreneurship refers to a specific business: entrepreneurship is an independent activity, and its activity is said to be income as a result of the use of property, the sale of tokens, the performance of a particular job or the provision of services, at certain risks"[10]. Sh.Shodmonov, T.Jo raev describes entrepreneurship as "entrepreneurial activity is an activity aimed at profit making"[11]. V.M.Vlasova explains that "entrepreneurship is a special production factor, which collects all omillarni into one system during the production process"[12].

In our opinion, entrepreneurship: if a definition is given from the youth activity: entrepreneurship is a process of active application of young people to life, embodying their knowledge, knowledge, potential, working in production in the process of modernization. The more knowledge the youth has the potential to manage production, the higher the economic effect of its activities in the economic process. During the former
Union, the entrepreneurial activity of young people was generally limited.

It is necessary to draw conclusions from these points that one of the forces that drives our society to action is youth. Enthusiasm, effort, initiative in them occupy a leading place in various spheres of the economy in a wide range. This means that young people are engaged in agriculture, heavy and Light Industry, Entrepreneurship, attracting foreign investment, bringing secular progressive experiences to life. In the process, it is necessary to rely on young people who are not afraid of such risks, who think about themselves and the fate of Vatan, even if they risk their activities.

Consequently, the provision of economic development covers various fronts. Zero, Sh.As Mirziyoyev noted, following the rule that" without achieving economic independence, political independence can not be ensured", we will continue to consistently increase the economic power of our country, ensure its competitiveness on the world arena, modernize the economy.[13] first of all, it should be noted that as noted in the Constitution of the Republic of Uzbekistan: (Article 53)"the basis of the economy of Uzbekistan, which is aimed at developing market relations, is property of various forms. The state guarantees freedom of entrepreneurship and labor, equal rights of all forms of ownership and equal protection of legal aspects, taking into account the superiority of the right of consumers.

Private property, like other forms of property, is inviolable and protected by the state. The owner can be deprived of his property only in cases provided for by law and in order.[14] or Article 54. "The owner owns his property, uses it and dispose of it. The use of property must not cause damage to the ecological 
environment, violate the rights of citizens, legal entities and the state, as well as interests protected by law.[15] in this regard, we can say that the new Uzbekistan also corresponds to the fundamental essence of the Constitution.

It's no secret that many countries that have gained independence are eagerly looking at the development of Uzbekistan and the reforms ongoing. The reason for this is the provision of economic development in our Republic, priority from politics.

As noted above, the role of the state at the top of the reforms in the process of transition to market relations is shown. Therefore, our state, the Cabinet of Ministers adopted important decisions on reforms, which form the basis of the sustainable development of the society under construction in our country.

Since the development of society is primarily concerned with the development of the economy, we must not forget that economics is the main factor that ensures the survival of people in society. Historical data on this point indicate that people seek to consume material pleasures as they step into life. For this reason, the economy is also a key factor for the functioning of people. The history of mankind shows that people have sought sources and omens from various sectors for the development of the economy. As a result, they made a significant contribution to the development of the economy in their time. After gaining independence, the Republic of Uzbekistan faced various difficulties in the economic sphere. Because, despite the efforts to implement the plan of economic development during the former Union, the population of Uzbekistan did not use it as it pleases. The activities of the Republic were managed through the center and serious shortcomings were allowed in ensuring the well-being of the population.

\section{CONCLUSION}

The conclusion is that, first of all, these principles are the basis for the activity of the people, especially young people, as this development of the world community creates a definition.. Secondly, these principles confirmed their viability over the past period and increased overall activity. Third, the restoration of human, legal, democratic and civil society in Uzbekistan is largely associated with the activity of the population of this Republic. This activity is also embodied in the activities of more and more young people. From the quatrain, the activity of young people depends on the objects of Labor... And labor is a source of activity. Fifth, strengthening youth activity is also linked to the study of historical historical sources. Conclusion from the past depends on the potential of each age. From gold, the "strategy of action" in the understanding of the priority of the economy of young people over politics and its application to practical activities serves as a methodology.

\section{REFERENCE}

1. http://uza.uz/oz/politics/zbekistonrespublikasi-prezidenti-shavkatmirziyeevning-oliy-25-01-2020

2. Sh.Mirziyoev An educated generation is a guarantee of a great future, an enterprising people is a guarantee of a prosperous life, and friendly cooperation is a guarantee of development. $\mathrm{T}$.: “Uzbekistan" 2018 Pages 13-14

3. M.Sharifkhodjaev., Z.Davronov TMI "Fundamentals of spirituality": 2005, 101 pages.

4. Sharopov F.Sh. Political science. Political system analysis. Fundamentals of political culture. Book 2. T .: 1996, p.97.

5. Short political dictionary M., 1989 Political science. Encyclopedic dictionary. 
Publishing House of Moscow Commercial University. M., 1993, 259 p.

6. Sh.Mirziyoev We will resolutely continue our path of national development and raise it to a new level. T .: "Uzbekistan" 2019, volume 1, page 46

7. Sh.Mirziyoev We will resolutely continue our path of national development and raise it to a new level. T .: "Uzbekistan" 2019, Volume 1, page 145

8. Reisberg B.A. Basics of business. M., 1996, $7 \mathrm{p}$.

9. Shestakov AV Entrepreneurial activity. Sergeev AA Economic bases of business planning. M., 1999, $303 \mathrm{P}$
10. Ilyukhin V.Ya. Economic theory. Lawyer. Moscow., 2000

11. Sh. Shodmonov., T. Juraev. Economic theory. T .: 2000, p.121.

12. Modern economics for university students. Textbook. Phoenix. Rostov on Don., 1998, 320 p.

13. Sh. Mirziyoev We will build our great future together with our brave and noble people. T.: "Uzbekistan" 2016, p.85

14. Constitution of the Republic of Uzbekistan T .: “Uzbekistan" 2017, pp. 11-12.

15. The Constitution of the Republic of Uzbekistan T .: “Uzbekistan” 2017, p. 